\title{
Humidification therapy; long-term effects in COPD and OSAS patients
}

\author{
Dorina ESENDAĞLI ${ }^{1}$ \\ Sevinç SARINÇ ULAŞLI ${ }^{2}$ \\ Antonio ESQUINAS ${ }^{3}$
}

1 Clinic of Chest Diseases, Ankara Hospital, Baskent University, Ankara, Turkey

${ }^{1}$ Başkent Üniversitesi Ankara Hastanesi, Gögüs Hastalıkları Kliniği, Ankara, Türkiye

2 Department of Chest Diseases, Faculty of Medicine, Hacettepe University, Ankara, Turkey

2 Hacettepe Üniversitesi Tıp Fakültesi, Gögüs Hastalıkları Anabilim Dalı, Ankara, Türkiye

3 Intensive Care Unit, Morales Meseguer Hospital, Murcia, Spain

${ }^{3}$ Morales Meseguer Hastanesi, Yoğun Bakım Ünitesi, Murcia, İspanya

\section{SUMMARY}

\section{Humidification therapy; long-term effects in COPD and OSAS patients}

Humidification therapy is widely used in patients during invasive ventilation and the importance of heating and humidifying the inhaled air is well defined in both the acute and long term setting. On the other hand the continuous usage of humidification in noninvasive ventilation is controversial and the long term effects are still not well defined. The usage of noninvasive ventilation is especially important in hypercapnic Chronic obstructive pulmonary disease (COPD) and also the obstructive sleep apnea syndrome (OSAS) patients and compliance to this treatment is essential in long term. Limited number of studies have shown that heated humidification is preferred by COPD patients and might help in mucus clearance, reduce mucus viscosity and help in expectoration, but there was shown no priority as far as concerns the lung function or blood gas parameters. Humidification might also be important in long term oxygen treatment since the inhalation of dry air can lead to ciliary dysfunction, alterations in mucus properties and mucociliary clearance impairment. Studies concerning OSAS patients showed that humidification helps to reduce the nasal symptoms but plays no role in increasing the compliance of patients in long term. Multi-center studies with large number of patients are needed to identify patients' groups who are likely to benefit from the addition of humidification to noninvasive therapy.

Key words: Humidification, noninvasive ventilation, COPD, OSAS, long-term

\section{ÖZET}

\section{Nemlendirme tedavisi; KOAH ve OUAS hastalarında uzun vadeli etkileri}

Nemlendirme tedavisi, invaziv ventilasyon sırasında yaygın olarak kullanılmaktadır ve inhale havayı ısıtmanın ve nemlendirmenin önemi hem akut hem de uzun vadeli sonuçlarla iyi tanımlanmıştır. Öte yandan noninvaziv ventilasyonda sürekli nemlendirmenin kullanımı tartışmalıdır ve uzun vadeli etkileri hala iyi tanımlanmamıştır. Hiperkapnik kronik obstruktif akciğer hastalığı (KOAH)'nda ve obstrüktif uyku apne sendromu (OUAS) hastalarında noninvaziv ventilasyon kullanımı özellikle önemlidir ve bu tedaviye uyum uzun vadede önemlidir. Sınırlı sayıda yapılan çalışmalar, ısııılmış nemlendirme işleminin $\mathrm{KOAH}$ hastaları tarafından tercih edildiğini ve mukus temizlenmesinde, mukus viskozitesinde azalmaya ve balgam söktürmede yardımcı olabileceğini ancak akciğer fonksiyonu veya kan gazı parametreleri ile ilgili herhangi bir önceliğe sahip olmadığını göstermiştir. Kuru havanın inhalasyonu siliyer disfonksi-

\section{Yazışma Adresi (Address for Correspondence)}

Dr. Dorina ESENDAĞLI

Başkent Üniversitesi Ankara Hastanesi, Göğüs Hastalıkları Bölümü, ANKARA - TURKEY

e-mail: dorinarama@hotmail.com 
yona, mukus değişikliğe ve mukosiliyer temizleme bozukluğuna neden olabileceğinden, nemlendirme uzun süreli oksijen tedavisinde de önemli olabilir. OUAS hastaları ile ilgili yapılan çalısmalar, nemlendirme, burun belirtilerini azaltmaya yardımcı olduğunu ancak uzun vadede hastaların uyumluluğunu arttırmada rol oynamadığını göstermiştir. Noninvaziv tedaviye nemlendirmenin eklenmesinden fayda sağlayacak hastaların gruplarını belirlemek için daha çok sayıda hastayla yapılan çok merkezli çalışmalara ihtiyaç vardır.

Anahtar kelimeler: Nemlendirme, noninvaziv ventilasyon, KOAH, OSAS, uzun vadeli

Humidification is the process of increasing relative humidity of the atmosphere. In the setting of respiratory medicine, humidification during invasive ventilation is a standard of care. Heated humidifier $(\mathrm{HH})$ and the heat-and-moisture exchanger (HME) are the humidification methods. The importance of heating and humidifying the inhaled air is well defined for patients undergoing invasive ventilation in both the acute and long-term setting $(1,2)$. The routine use of humidification and long term effects in patients receiving noninvasive ventilation (NIV) treatment is controversial. Improvements in mucociliary clearance with humidification have been demonstrated in patients with bronchiectasis and chronic obstructive pulmonary diseases (COPD) (3). However, there is no consensus statement defining the indications, patient selection, and technical issues.

In this review, effects of humidification in COPD and obstructive sleep apnea syndrome (OSAS) will be discussed by focusing mainly on the role of humidification for improving the adherence of patients with OSAS to continuous positive airway pressure (CPAP) therapy and long term effects of humidification in COPD.

\section{Humidification Therapy in COPD Patients}

The main complaints of COPD patients consist of dyspnea, chronic cough and sputum production. The retention of mucus due to impaired mucociliary transport and an increase in its overall secretion leads to the formation of a "suitable" microenvironment for bacteria growth which further "alarms" the immune system cells especially neutrophils to migrate to the airways and start the inflammatory process. This is a common scenario which occurs in exacerbations and leads to a deterioration of the patients' clinical outcome. There are many studies that have shown a positive association of sputum production and decline in lung function, hospitalization and death (4-7). It is important to treat these patients appropriately but it is also essential to take measures for the prevention of such exacerabations. Smoking cessation, vaccination (flu and pneumococcus), physical activity and pul- monary rehabilitation are examples of non-pharmacological management of COPD patients to improve the quality of life. Different treatment strategies to facilitate the mucus clearance and reverse the hypersecretion have also been developed. Wolkove et al. have reported an increase in bronchodilator response in stable COPD patients after using a mucus clearing device (8). On the other hand eventhough not recommended by guidelines due to lack of well designed studies, a variety of mucolytics and antioxidants have been developed and seem to be efficacious in patients prone to infections (9). In recent years some studies have shown that humidification therapy might help in mucus clearance, reduce mucus viscosity and help in expectoration in airway diseases. Hasani et al. showed that even a short-term application of humidification therapy consisting of 3 hours per day for a period of one week increased significantly the mucociliary clearance in patients with bronchieactasis, a disorder which is also characterized with sputum retention due to abnormal widening of the bronchi and their branches (10). In order to determine the long-term effects of the humidification therapy in COPD and bronchectasis patients Rea and colleagues randomized 108 patients to daily humidification or usual care and followed them for 12 months (3). The humidified air at $37^{\circ} \mathrm{C}$ at a flow rate of $20-25 \mathrm{~L} / \mathrm{min}$ was given by the help of a nasal cannulae and the overall mean time of usage was registered as 1.6 $(\mathrm{SD}=0.67)$ hours per day. At the end this study showed that patients on humidification therapy had fewer exacerbations days, longer period to next exacerbation and reduced exacerbation frequency statistically significant when compared to usual care group. The impact of the humidification therapy was also observed in both quality of life scores and improvement of pulmonary funciton tests at the end of the $3^{\text {rd }}$ and $12^{\text {th }}$ month of the study (3).

Long-term oxygen therapy for at least 15 hours per day is used in COPD patients with chronic respiratory failure in order to improve pulmonary hemodynamics. Nasal oxygen therapy can be administered with or without humidification. In routine practice 
nasal oxygen therapy is administered without humidification. Inhalation of dry air can lead to ciliary dysfunction, alterations in mucus properties and mucociliary clearance impairment $(11,12)$.

However, the effects of humidification or no humidification on mucociliary transport, mucus properties, and airway symptoms in patients receiving long-term oxygen therapy are not well established. In the study by Franchini et al., cold bubble humidification did not prevent slowing of mucociliary clearance, mucus dehydration, and worsening pulmonary function; cold bubble humidification performed no better than no humidification (13).

Another encountered problem in COPD patients who recieve oxygen therapy is the development of hypercapnia (14). NIMV is often used in exacerbations and also stable hypercapneic COPD patients and it is important to increase the compliance of the patients for the device. It was reported previously that the majority of patients who are prescribed NIMV for usage at home drop out within the first month due to skin irritation, upper airway problems or air leakage (15). Nava and colleagues designed a randomized crossover pilot study for a period of 12 months to compare the clinical effects of heated humidification at $34^{\circ} \mathrm{C}$ with heat and mositure exchanger during a long-term NIMV application in stable hypercapneic patients. There was no significant difference between the groups as far as concers the tolerance and side effects, but the patient number was only eight for each group and interestingly the majority of the patients at the end of the study prefered the heated humidification system for their treatment at home (16). In another study the role of humidification on ventilatory and blood gas parameters was investigated on 81 patients of whom 52 were hypercapneic (17). Lellouche et al. did not recommend HME use with NIV due to the increased additional dead space with decreasing carbondioxide elimination in hypercapnic subjects (17).

On the other hand there are no studies which compare the "humidification" and "no humidification" systems and large randomized studies are also needed for the comparison of different humidification systems and their effect on upper airway infections.

Another important issue is whether the long-term application of such systems is cost effective or not. Milne et al. performed an economic evaluation of the 87 patients who were enrolled in a previous study for the long term humidification therapy for a period of 12 months $(3,18)$. They found that humidification therapy applied to moderate, severe chronic pulmonary disease and bronchectasis patients was cost-effective at a level acceptable for public funding in New Zealand (18). Yet this study has got limitations concerning the sample size, the lack of blinding and being focused on only one country. Further studies with the involvement of more countries and a larger number of patients are needed to enlighten such economical issues.

\section{Humidification Therapy in OSAS Patients}

NIMV is also the treatment of choice in obstructive sleep apnea, a disorder which is characterised by the episodic collapse of the upper airway which further leads to hypoxemia and an increase in breathing effort resulting in arousal (19). This sleep disorder if left untreated leads to an excessive daytime sleepiness, impaired neurocognitive function, increase in accidents for drivers and is also related to other common sistemic disorders like hypertension, stroke and myocardial infarction (19).

CPAP, the first-line medical treatment in adults with OSAS, effectively improves sleep architecture, reduces the apnea-hypopnea index (AHI), normalizes oxyhemoglobin saturation, and decreases neurocognitive and cardiovascular sequences $(19,20)$. Eventhough all these beneficial effects are extensively reported, the adherence rates of patients to treatment which is defined as at least 4 hours per day in at least 5 days of a week was calculated to be in average as only $\% 80$ initially and half of the patients usually stop using CPAP after one year (21). The need for continous use and the belief of patients that the disease can be cured might have lead to such results but another important reason for dropping out are the side effects of the treatment itself. Most commonly seen adverse effects are the upper airway symptoms $(46-73 \%)$ like nasal congestion, dry nose, mouth and throat and discomfort associated with cold air (22). Strategies to improve adherence to CPAP that have been tested are broadly categorized as educational, technological, psychosocial, pharmacological, and multi-dimensional. Different types of interventions to increase adherence of CPAP mainly the addition of humidification has been studied, but the results remain contradictory. In a prospective cross over study 44 patients with OSA were randomised to either CPAP with controlled heated breathing tube or 
CPAP without humidification for one night and vice versa for the second night. Then the patients were randomised again for home treatment for a period of 4 weeks (23). The results of the study showed no improvement on compliance or quality of life, but in the first 2 nights of treatment dryness of mouth decreased and the subjective sleep quality measured by questionnaires was in favor of humidification therapy (23). On the other hand in controlled heated breathing tube usage as the condensation is prevented within tube it can cause wetness on face. Similiarly in this study the wake up due to wetness on face was increased, which means the adjustment of temperature and humidity level should be carefully monitored (23).

Massie et al. in a short term study randomised patients starting CPAP treatment into 2 groups: cold humidificiation or heated humidification for 3 weeks and then a washout period of 2 weeks which consisted of no humidfication was applied (24). Compliance, satisfaction of treatment and feeling refreshed on awaking were significantly higher in heated humidification group. Side effects like dry nose, mouth and throat were less frequent with heated humidification when compared to CPAP without humidity (24). Similiarly Neill et al. compared heated humidification versus placebo humidification in a short term (3 weeks) randomised study and found that compliance increased slightly especially at the end of the first week with humidification and upper airway adverse effects decreased, but there was no difference in sleepiness or satisfaction degree of the patients (25).

On the other hand, Wiest et al. showed that the usage of prophylactic humidification in the initial titration of untreated OSAS patients did not improve the acceptance or increase the comfort of the treatment (26). Similiarly Duog et al. in a randomised parallel double blinded controlled study, showed no additional benefit of humidification in nasal symptoms at the initial titration thus not recommending its usage routinely (27). Taking in consideration the results of these short term studies it seems like the group of patients who might benefit more from the humidification therapy are the ones who present or complain about upper airway symptoms while using CPAP. Rokatonanahary et al. in their study included only patients with nasal symptoms and showed that heated humidification did increase the compliance of CPAP treatment significantly in this group of patients. They also defined risk factors which might lead to upper airway symptoms like age over 60 years, usage of drugs that lead to dryness of mucosa, presence of chronic nasal mucosal disease and prior surgery like uvulopalatopharyngoplasty (28).

Another problem in patients with nasal symptoms is the increase in mouth leaks which further increases drying of nasal mucosa, the nasal resistance and nasal mucosal blood flux leading to a vicious cycle. Breathing and mouth leakage reduce humidity 80 to $40 \%$ and the addition of heated humidification can increase the humidity level up to $60 \%$ and reduce the water loss during respiration by $\% 38(23,29)$. Wiest et al. in a study with 24 patients showed that the heated humidification reduces upper airway dryness during CPAP (30). Similiarly Arajuo et al. reported a decrease in dehydration effect of inspired air when humidification was added to CPAP therapy (31). Cruz et al. showed that cold and dry air can lead to epithelial cell damage and speculated that this might be due to a mucosal water transportation defect which explains why the heated humidification leads to clinical improvement (32).

As the CPAP treatment is usually recommended for continous and life-time usage it is important to know the long term effect of humidification on this treatment. Mador and colleagues in a randomized controlled trial compared heated humidification to the standard care (22). Ninety eight patients with OSAS who did not recieve CPAP treatment previously were randomised and then evaluated at periods of 1,3 and 12 months. The patients included in control group who developed upper airway symptoms that could not be treated by simple measures were switched to the heated humidification group. At the end of the study the results were similiar to short term studies. Symptoms like dry nose, mouth and throat were found to be less frequent in heated humidification group, but no difference in compliance, quality of life or subjective sleepiness was detected between groups (22). In another study Worsnop and colleagues evaluated patients with OSAS randomised to humidification versus no humidification groups for a period of 12 weeks. Heated humidification reduced nasal symptoms like dry nose, dry mouth and sneezing, but did not improve the overall adherence (33).

Kline and Carlson compared heated versus cold and no-humidification addition to CPAP therapy for a period of 3 months and there was found no difference in compliance rates between groups, but the 
frequency of drop-outs were seen more in the group recieving CPAP without humidification. The patients recieving heated humidification were the ones that had fewer complaints of nasal symptoms (34).

The delivery of humidity in CPAP treatment can be influenced by the cool room temperatures e.g. during winter season, as the decrease of the temperature of air can reduce the maximum level of moisture that the air can hold and also cause the accumulation of water in breathing tube and increase in pressure swings in the mask during respiration. Nilius et al. in a randomized controlled crossover trial showed that the integrated humidifier in CPAP equipment reduced singificantly the condensation amount and this lead to an increase in total sleep time, longer stage 3, 4 and REM sleep and decrease in overall side effects even when the room temperature was adjusted below $20^{\circ} \mathrm{C}(35)$.

Another issue is how to convience the non-compliant patients to turn back to treatment. Ballard et al. conducted a study in 204 non-compliant OSAS patients. They found that only $24 \%$ of them became compliant after interventions like mask optimization, heated humidification, topical nasal therapy and especially education for a period of 2 weeks (21). Addition of heated humidification alone had no detectable effect upon outcome, but $82 \%$ of patients had already previously recieved humidification with their CPAP treatment which means additional humidification is of no benefit. Education and supportive counselling were the measures shown to be the most effective to make non-compliant patients turn back to their treatment (21). Similiarly Wiese et al. in their study compared OSAS patients' compliance in respect of video education (36). A 15 minute video showing two OSAS patients talking about their disease and its treatment was viewed to one group of patients and then compliance of the patients were compared to the ones who were not shown the video. The patients who watched the video at their first clinic were more likely to use the treatment and improvement in the rate of return of patients to the follow up was detected (36). This does emphasize that education of patients is quite important for the treatment compliance and video education might be a simple choice.

Obstructive sleep apnea is associated with upper airway and systemic inflammation as CRP and cytokines level increase in these patients. The release of inflammatory mediators can cause the development of the upper airway symptoms. On the other hand Constantinidis et al. demonstrated a prolonged mucocialiary transport time, dessication of the epithelial surface and an inflammatory cell infiltration of mucosa after 3-10 months of CPAP usage (37). CPAP itself can disrupt the equlibrium of mucous membrane and increase the inflammation of nasal mucosa (38). So not only the OSA disorder but also its treatment can cause upper airway inflammation and it is crucial to take measures for minimizing or treating such conditions. 20 patients with OSA, who exhibited symptomatic nasal obstruction were randomised to recieve 3 weeks of CPAP with heated humidification or with sham-heated therapy followed by 3 weeks of the reverse treatment respectively. Measures of cytokines from the nasal lavage showed a decrease in pro-inflammatory cytokines: IL-6,-12 and TNF- $\alpha$ in the heated humidification group. In addition a decrease in nasal symptomatology, resistance, attenuation of inflammatory cells infiltration and degree of fibrosis of the nasal mucosa was detected in the humidification group when compared to the control (38).

What about the inflammatory process at the lower airway system? Is it a part of the scenario as well? Devoussaus et al. detected bronchial neutrophilia at a level seen in COPD patients especially smokers and a high IL-8 level in untreated OSAS patients when compared to controls (39). Even after one month of CPAP treatment no change in inlammatory profile was detected. In addition an increase in airway hyperresponsiveness without changes in pulmonary function tests was noted (39). In COPD patients the increase of inflammation could be explained by factors like smoking, but OSA patients involved in this study were all non-smokers. Possible mechanisms involved in inflammation of airways in OSAS can be variable. Muscle hyperactivity commonly seen in this disorder is associated with local muscular proinflammatory cytokine production. On the other hand desaturation-reoxygenation can lead to an increase in oxidative stress. Other comorbidities like gastro esophageal reflux disease, microaspirations, obesity might lead to a pro-inflammatory state as well (39). Yet we still do not know the long term effect of CPAP and humidification on airway inflammation and studies addressing this issue should be carefully planned. A treatment choice for upper airway inflammation might be corticosteroids. Topical nasal steroids are frequently prescribed as an alterna- 
tive approach to treat nasal complaints associated with CPAP especially allergic rhinitis. Ryan and colleagues in their study randomised 125 patients with AHI score $\geq 10 / h$, who already used CPAP into 3 groups: CPAP without humidification, with heated humidification and regular topical nasal steroids application in addition to CPAP therapy for a period of 4 weeks (40). They found no difference in compliance between groups, but nasal symptoms were less frequent in humidification group. Topical nasal steroid usage was found to be inferior when compared to heated humidification as far as concerns the incidence of nasal side effects, thus concluding that nasal steroids should not be prescribed routinely to these patients (40).

The difference in results in various studies might be due to difficulty in study design, lack of reproducibility, a low number of patients involved, especially the control group, lack of blindness, difficulty to follow-up patients and their outcomes or side effects and questionnaires which remain a subjective type of evaluation. The major clinical challenge is to improve the long term adherence to CPAP treatment. Eventhough in the majority of studies the addition of humidification did not show a significant improvement for compliance it should be kept in mind that adherence might be also affected from other factors like relief of symptoms related to OSAS, mask comfort, disease severity rather than isolated nasal symptoms. Improvement of side effects are quite important for the treatment adherence and more studies about the long-term effect of humidification are needed to elucidate the overall role it plays in treatment of not only OSAS patients but all the others who need noninvasive mechanichal ventilation.

\section{CONCLUSION}

Based on the available data proper humidification systems may improve the outcomes of patients receiving NIV. Multi-center studies with large number of patients are needed to identify patients' groups who are likely to benefit from the addition of humidification to NIV therapy and to assess the effect of humidification on adherence to NIV, and its effect on different outcome measures.

\section{REFERENCES}

1. Jiang M, Song Jl, Guo XL, et al. Airway Humidification Reduces the Inflammatory Response During Mechanical Ventilation. Respir Care 2015;60(12):1720-8.

2. Branson RD. Humidification of respired gases during mechanical ventilation: mechanical considerations. Respir Care Clin N Am 2006;12(2):253-61.

3. Rea $H, M c A u l e y ~ S$, Jayaram $L$, et al. The clinical utility of long-term humidification therapy in chronic airway disease. Respir Med 2010;104(4):525-33.

4. Annesi I, Kauffmann F. Is respiratory mucus hypersecretion really an innocent disorder? A 22-year mortality survey of 1,061 working men. Am Rev Respir Dis 1986;134(4):68893.

5. Vestbo J, Prescott E, Lange P. Association of chronic mucus hypersecretion with FEV 1 decline and chronic obstructive pulmonary disease morbidity. Copenhagen City Heart Study Group. Am I Respir Crit Care Med 1996;153(5):15305.

6. Lange P, Nyboe J, Appleyard M, Jensen G, Schnohr P. Relation of ventilator impairment and of chronic mucus hypersecretion to mortality from obstructive lung disease and from all causes. Thorax 1990;45(8):579-85.

7. Speizer FE, Fay ME, Dockery DW, Ferris BG Jr. Chronic obstructive pulmonary disease mortality in six U.S. cities. Am Rev Respir Dis 1989; 140:S49-55.

8. Wolkove N, Kamel H, Rotaple M, Baltzan MA Jr. Use of a mucus clearance device enhances the bronchodilator response in patients with stable COPD. Chest 2002; 121(3):702-7.

9. Rogers DF, Rubin BK. Mucolytics for COPD, Chronic Obstructive Pulmonary Disease, In: Stockley, Rennard, Rabe, Celi (eds). Chapter 62. 2007:756-68.

10. Hasani A, Chapman TH, McCool D, Smith RE, Dilworth JP, Agnew JE. Domiciliary humidification improves lung mucociliary clearance in patients with bronchiectasis. Chron Respir Dis 2008;5(2):81-6.

11. Chalon J, Loew DA, Malebranche J. Effects of dry anesthetic gases on tracheobronchial ciliated epithelium. Anesthesiology 1972;37(3):338-43.

12. Salah B, Dinh Xuan AT, Fouilladieu IL, Lockhart A, Regnard J. Nasal mucociliary transport in healthy subjects is slower when breathing dry air. Eur Respir J 1988;1(9):852-5.

13. Franchini ML, Athanazio R, Amato-Lourenço $L F$, et al. Oxygen with cold bubble humidification is no better than dry oxygen in preventing mucus dehydration, decreased mucociliary clearance, and decline in pulmonary function. Chest 2016;2.

14. Cousins JL, Wark PA, McDonald VM. Acute oxygen therapy: a review of prescribing and delivery practices. Int I Chron Obstruct Pulmon Dis 2016;11:1067-75.

15. Criner GJ, Brennan K, Travaline JM, Kreimer D. Efficacy and compliance with noninvasive positive pressure ventilation in patients with chronic respiratory failure. Chest 1999;116(3):667-75. 
16. Nava S, Cirio S, Fanfulla F, et al. Comparison of two humidification systems for long-term noninvasive mechanical ventilation. Eur Respir J 2008;32(2):460-4.

17. Lellouche F, Pignataro C, Maggiore SM, et al. Short-term effects of humidification devices on respiratory pattern and arterial blood gases during noninvasive ventilation. Respir Care 2012;57(11):1879-86.

18. Milne RJ, Hockey $H$, Rea H. Long-term air humidification therapy is cost-effective for patients with moderate or severe chronic obstructive pulmonary disease or bronchiectasis. Value Health 2014;17(4):320-7.

19. Zhou J, Camacho M, Tang X, Kushida CA. A review of neurocognitive function and obstructive sleep apnea with or without daytime sleepiness. Sleep Med 2016. S13899457(16)00061-7.

20. Fatureto-Borges F, Lorenzi-Filho G, Drager LF. Effectiveness of continuous positive airway pressure in lowering blood pressure in patients with obstructive sleep apnea: a critical review of the literature. Integr Blood Press Control 2016;9: 43-7.

21. Ballard RD, Gay PC, Strollo PJ. Interventions to improve compliance in sleep apnea patients previously non-compliant with continuous positive airway pressure. I Clin Sleep Med 2007;3(7):706-12.

22. Mador MI, Krauza M, Pervez A, Pierce D, Braun M. Effect of heated humidification on compliance and quality of life in patients with sleep apnea using nasal continuous positive airway pressure. Chest 2005;128(4):2151-8.

23. Ruhle KH, Franke KJ, Domanski U, Nilius G. Quality of life, compliance, sleep and nasopharyngeal side effects during CPAP therapy with and without controlled heated humidification. Sleep Breath 2011;15(3):479-85.

24. Massie CA, Hart RW, Peralez K, Richards GN. Effects of humidification on nasal symptoms and compliance in sleep apnea patients using continuous positive airway pressure. Chest 1999;116(2):403-8.

25. Neill AM, Wai HS, Bannan SP, Beasley CR, Weatherall M, Campbell AJ. Humidified nasal continuous positive airway pressure in obstructive sleep apnoea. Eur Respir J 2003; 22(2):258-62.

26. Wiest GH, Harsch IA, Fuchs FS, et al. Initiation of CPAP therapy for OSA: does prophylactic humidification during CPAP pressure titration improve initial patient acceptance and comfort? Respiration. 2002; 69(5): 406-12.

27. Duong $M$, Jayaram L, Camfferman D, Catcheside P, Mykytyn I, McEvoy RD. Use of heated humidification during nasal CPAP titration in obstructive sleep apnoea syndrome. Eur Respir J 2005;26(4):679-85.
28. Rakotonanahary D, Pelletier-Fleury N, Gagnadoux F, Fleury $B$. Predictive factors for the need for additional humidification during nasal continuous positive airway pressure therapy. Chest 2001;119(2):460-5.

29. Randerath WJ, Meier J, Genger H, Domanski U, Rühle KH. Efficiency of cold passover and heated humidification under continuous positive airway pressure. Eur Respir I 2002;20(1):183-6.

30. Wiest GH, Lehnert G, Brûck WM, Meyer M, Hahn EG, Ficker JH. A heated humidifier reduces upper airway dryness during continuous positive airway pressure therapy. Respir Med 1999;93(1):21-6.

31. Martins De Araújo MT, Vieira SB, Vasquez EC, Fleury $B$. Heated humidification or face mask to prevent upper airway dryness during continuous positive airway pressure therapy. Chest 2000;117(1):142-7.

32. Cruz AA, Naclerio RM, Proud D, Togias A. Epithelial shedding is associated with nasal reactions to cold, dry air. I Allergy Clin Immunol 2006;117(6):1351-8.

33. Worsnop CJ, Miseski S, Rochford PD. Routine use of humidification with nasal continuous positive airway pressure. Intern Med J 2010;40(9):650-6.

34. Kline $L R$, Carlson P. NCPAP acceptance and compliance is altered by humidification. Sleep 1999;22:S230.

35. Nilius G, Domanski U, Franke KJ, Ruhle $\mathrm{KH}$. Impact of a controlled heated breathing tube humidifier on sleep quality during CPAP therapy in a cool sleeping environment. Eur Respir J 2008;31(4):830-6.

36. Jean Wiese H, Boethel C, Phillips B, Wilson JF, Peters J, Viggiano T. CPAP compliance: video education may help! Sleep Med 2005;6(2):171-4.

37. Constantinidis J, Knöbber D, Steinhart $H$, Kuhn J, Iro $H$. Fine-structural investigations of the effect of nCPAP-mask application on the nasal mucosa. Acta Otolaryngol 2000;120(3):432-7.

38. Koutsourelakis I, Vagiakis E, Perraki E, et al. Nasal inflammation in sleep apnoea patients using CPAP and effect of heated humidification. Eur Respir J 2011;37(3):587-94.

39. Devouassoux G, Lévy P, Rossini E, et al. Sleep apnea is associated with bronchial inflammation and continuous positive airway pressure-induced airway hyperresponsiveness. I Allergy Clin Immunol 2007;119(3):597-603.

40. Ryan S, Doherty LS, Nolan GM, McNicholas WT. Effects of heated humidification and topical steroids on compliance, nasal symptoms, and quality of life in patients with obstructive sleep apnea syndrome using nasal continuous positive airway pressure. J Clin Sleep Med 2009;5(5):422-7. 